\begin{tabular}{lcc}
\hline \multicolumn{3}{c}{ A N N A L E S } \\
UNIVERSITATIS & MARIAE CURIE-SKŁODOWSKA \\
LUBLIN - POLONIA & \\
VOL. XXIV, 1 & SECTIOK K \\
\hline
\end{tabular}

Faculty of Social Sciences, University of Wrocław, Poland

NORBERT TOMASZEWSKI

The Impact of the Internet 2.0 on the Voting Behaviour in the United
States of America - the Analysis of the 2016 Presidential Primaries

ABSTRACT

The aim of the article is to study, whether the voting behaviour of the electorate in the US can be heavily influenced by the use of social media during the political campaign. It also focuses on the celebrity endorsement, which is becoming one of the most important parts of the campaigning process in the United States. The article analyses the presidential primary campaigns of four most popular politicians who took part in the 2016 elections.

Key words: celebrity endorsement, social media, Internet 2.0, voting behaviour in the United States, presidential primaries, political marketing

\title{
INTRODUCTION AND THE THEORETICAL BACKGROUND
}

Before its era, the Internet has mostly been used for the search of the information and access to needed data. According to the theory of Christian Fuchs et al., the Internet has been transformed in the past years from a system that is primarily oriented to information provision into a system that is more oriented to communication and community building [Fuchs et al. 2012: 3]. With more and more people gaining access to this medium, people, who were using the Internet, started to create the content which allowed to influence the opinion of other users, who interacted with their posts. The creation of such allowed the standard Internet users to express their views and to seek for the citizens, who share their political views. This new situation, however, has demolished the until this time order on which the political 
marketing and communication were based, mainly because the standard mass media have stopped meeting their and voters' expectations. The term "Internet 2.0" has been popularized by O'Reilly Media Group, which in 2004 organized a number of conferences during which this phenomenon has been narrowly described. As the founder of O'Reilly Media, Tim O'Reilly, has described, thanks to the evolution of the Internet, standard media, which were focusing on the creation of their ideas, allowed the users to take part in their process and share the feedback regarding their outcome [O'Reilly 2005]. Furthermore, he explains how the users can communicate with each other, by sharing and exchanging the content which led to a new form of cyber-socializing, through blogs and other social-related concepts such as social media portals, chats and user applications [O'Reilly 2005]. From this moment, which was a milestone for the world wide web, the specified user data, that has been left by one, was not only a trace of one citizen on the Internet, it was their personality which has been created through the expression of their views and interests. In order to let the user find the similar content, cookies applications have been created, which allowed their devices not only to remember their choices, but also to influence them by suggesting similar subject of their thoughts. This led to a new way of political activism which focused on the new media and, of course, has been recognized by the interest groups which wanted to establish relationships with the citizens. It was only a matter of time when the politicians themselves noted that such relation with their potential voters would be easier and more profitable; the political communication between the candidate and the voter depends on three variables: time, money and the quantity of people involved, therefore, thanks to the Internet, the campaign staff was able to gain the support of the bigger amount of potential voters, while spending less money and time on the campaign. According to the description of Girish Gulati and Christine Williams, from their paper written in 2007, focusing on the use of social media in political campaigns, social networks allow the candidates to control both the created content on their website and the way the users interact with it. What is more, they create the possibility for their users to contribute and even control the content, which may lead to the initiation of the content with other users, who share their political views [Gulati, Williams 2007: 4]. This situation has been anticipated by political experts for years, as the political advisor of the former President Bill Clinton, Dick Morris, has stated, the so-called "fifth estate" of Internet politics would alter the balance of political power in the United States by linking the people together [Howard, Chadwick 2010: 13].

When adopting the theoretical approach to this matter, my field of research focuses on a reinterpretation of the distinctive theories of Pierre Bourdieu. His scientific approach to the distinction, which is described as a willingness or a conscious intention of distinguishing oneself from common people [Bourdieu 1984: 31], in an ideal way describes the relations between the social groups, but encourages the opposite analysis when focusing on today's relations between the voters and the candidates. From my scientific point of view, in order to create a political campaign, which will 
be successful, a politician needs to show the voters their common political interests by approaching them on an equal level. By this statement, which is especially acknowledged in American politics, it can be stated that the politician needs to be seen by the voter as a person from their society, who is willing to represent their values, and not as a person, that comes from a better social surrounding, often associated with the political elites, that can a) teach them values on a pupil-master level or $b$ ) be considered as a better version of them, that offers them political promises related to their stands as an exchange for the vote. This anti-distinction can be shown in various ways, such as clothing, language or a shared cultural interest. The definition of the social marketing can be determined as a social construction process which can be analysed both as a way of delivering effective communication techniques from a provider (such as political actors) and an introduction of the willingness to increase the level of the prosperity of the whole society [Kotler, Armstrong 1990: 34]. An adaptation of this theory on the political marketing ground can be seen in Robert Wiszniowski's approach, who proposed to define the political marketing as an instrument provided for the candidates and their surroundings to succeed at the political market. As stated in his research, such creation and scrutiny of the voter's needs may lead to the creation of a political offer, that through meeting their expectations, that, when created at the right time and in the integrated society, could meet their political needs and aspirations [Wiszniowski 2000: 17]. Moreover, the description of the political marketing model can be divided into three separate sections which can be combined if needed. The theory of Jennifer Lees-Marshment preconceives three segments of the campaign approach that can be taken in their marketing: product orientation, sales orientation and market orientation [Lees-Marshment 2004]. These three values determine the principles of relationship marketing: product orientation focuses on their own or a party platform issuing the positions, while a sales orientation uses a market research to establish and apply the communication and advertising techniques that will persuade the voters [Gulati, Williams 2014: 188]. Furthermore, the third orientation (market orientation) uses these two objectives to respond to the voters' needs and to meet their demands [ibid.].

In recent years, an important aspect of this theory can be adopted with the implementation of the celebrity politics. Referring to the anti-distinction theory (that I have presented), celebrities nowadays, when involving in a political campaign process, can be a missing link between the voters and the candidates. During the times of a huge crisis of confidence in politicians, the politicians themselves have to get the trust of the people who are at the top of the public confidence measurements - famous people. Celebrities are viewed, especially by the people from their social background, as everyday citizens who were able to achieve success, generated by their talents and career paths. They are idolised and their fans can be easily influenced by their personal views. Their endorsement for the political parties or representatives can be effective and result in the endorsement from the citizens, which are under their influence because of age, ethnicity, gender, sexual orientation or other background in which they may feel 
the similarity. The theory formed by Erica Austin et al. acknowledges that the external celebrities (which are not physically involved in the election process) can attract media attention and, thus, influence their followers to think positively about the political process, therefore, having the potential to reach out and mobilize the apathetic public [Austin et al. 2008]. Celebrity political endorsement has been described as the use of celebrity endorsement instruments for the purpose of political activities, especially election campaigning [Henneberg, Chen 2008: 4]. Such thesis can easily be implemented when focusing on the young voters in the United States, who are more likely to agree with a position when a pop culture celebrity endorses it [Jackson 2008]. In order to understand the mechanism, Alex Marland and Mireille Lalancette have distinguished two types of the external celebrity endorsements: celebrity political endorsements (CPE) publicists and fundraisers [Marland, Lalancette 2014: 135]. Although these both types of celebrities have different goals - the CPE publicists focus on the generation of media coverage and bringing the buzz, whereas the CPE fundraisers raise money for the candidate while gaining more resources to the campaign - there are no strict rules in acknowledging them. What is more, each of the celebrities may easily fit into these two roles, without compromising their support.

Based on this theoretical background, the main purpose of this article is to analyse the relationship between the social media and the presidential primary campaigns in 2016 in the United States. By analysing the social media activity of the main four candidates (respectively Bernie Sanders and Hillary Clinton in the Democratic Party primaries and Donald Trump and Ted Cruz in the Republican Party primaries), there can be generated an answer to the question whether the evolving world of the social media and the Internet 2.0 has an impact on the campaigning style and the outcome of the primaries. This study also focuses on the voting behaviour of American citizens and whether their activity can be influenced by their Internet use. On the other hand, it spotlights on how the campaign staff of the candidate can extend the use of social media to create the bond with the voter and transform him from the standard voting citizen to a person who, through their Internet activity, can engage into the campaigning process. With the campaigning style constantly evolving, especially during the last ten years, in this article I also wanted to focus on the field of celebrity politics, which is still quite a new sphere for the political marketing, but is intimately linked to the evolving world of social media, especially in conjunction with the impact which celebrities may have on an electoral behaviour of voters.

\section{GETTING THERE: TRANSFORMING THE POLITICAL CAMPAIGNS INTO THE NEW MEDIA-ORIENTED MODELS}

From my academic observation, the first elections that have made the ties between the political campaign and social media visible and important for the very first time, were the midterm elections of 2006, during which the candidates were canvassing for 
all of the House of Representatives seats and the one-third of the United State Senate seats. The decrease of voters' trust for the Republicans, triggered by the involvement of the Congress in the Terri Schiavo case and the scandals related to the Republican representatives such as Tom DeLay's, House Majority Leader's campaign process trial brought by the money laundering charges, have made it easy for the Democrats to win. Their result, however, was also driven by a social media campaign that has been more effective than the Republican campaign. With the growing popularity of social media tools such as Facebook and the golden era of MySpace, the candidates were able to reach their supporters. These websites allowed the candidates to reach their youngest voters who were using the Internet on a daily basis and were active in the social media community. That is why Facebook decided to let the candidates create their fanpages, which would let them communicate with the electorate, and their developers created a program called Election Pulse, which enabled the users to see how popular the candidates were within the Facebook audience [Harvey 2013: 490]. According to the research, almost one-third of the candidates running to the Senate and one in ten candidates running for the House of Representatives were in some way involved in the use of this program [Gulati, Williams 2007: 6]. This research has shown that not only the voters are more eager to support Democrats using the Internet, but also that Democrat nominees have engaged in more social media-related activities in order to gain the trust of the voters. When analysing the top ten most popular nominees from the 2006 midterm elections, one can observe a landslide victory for the Democratic Party - nine of their candidates were able to reach the top ten table with Hillary Clinton climbing to the top spot by receiving 12,038 voices of support on Facebook [Gulati, Williams 2007: 7].

The role of MySpace in the 2006 elections was nonetheless slightly different. Its aim was mainly to promote the registration of the voters - in regard to the cooperation with a group called Declare Yourself, MySpace started to run registration ads and, what is more, allowed the members to set a tool on their profile page called "I Registered to Vote on MySpace", which was a badge visible on their member profile [Gueorguieva 2009: 240]. The social media were also a tool of help for the fundraising during the campaign - some of the candidates have even started their own social networking websites, which allowed their users to raise money for them and engage with other supporters by inviting friends and creating events - the campaign of Barack Obama, for example, was based on such a successful idea [Gueorguieva 2009: 243].

Before I focus on the current campaign, there is another campaign that is a milestone for the use of social media in politics. When Hillary Clinton announced her start in the campaign for the Democratic nomination for the White House in 2008, she decided to use the mechanism that has already given her wide support in the 2006 elections her decision to deliver a video launched on her website was widely acclaimed by the political marketing specialists. This, however, has not been a game-changing idea, because on 16 January 2007, four days earlier, Barack Obama did the same. From this 
point, it became obvious that with the growing popularity of Facebook and other social media tools, this campaign may change the way the political campaigning works by decreasing the role of standard media, which were slowly replaced by the Internet 2.0 communication with the voters. Once again it could be observed that Democrats were dominating in the Internet campaigning sphere, which allowed them to receive more media attention than was given to Republicans in the nominee race. According to Costas Panagopoulos, by analysing the 2008 elections, "The election strategists were able to realize the Web's true potential and gain new ideas about how to gauge the relative influence of new media campaign tactics on vote choice" [Panagopoulos 2009: 3]. The authors identified a few areas that the candidates could gain from, while using the social media, starting with the online fund-raising, which, with the use of the Internet 2.0 resources, could help the candidates receive the small donations from the thousands of voters following their profiles. By creating the personalized videos addressed to the voters, the candidates were able to show the anti-distinction - they appeared to the citizens as ordinary people, who shared with them their past history and future plans. The second aspect of the turn to new media were the viral videos. In order to engage Internet users in their campaigns, politicians were creating the content that would let their voters not only watch it, but also comment on it and share it so that it could become available to more citizens. Hillary Clinton's “Choose My Theme Song” campaign in 2007 became a huge Internet phenomenon - Clinton released a video showing her singing abilities only to release another one few weeks later, addressing the negative comments and letting the voters choose her campaign song [Panagopoulos 2009: 6]. Thanks to this move, she seemed likeable and was able to engage people in her campaign. Obama, on the other hand, was highly profiting from the celebrity endorsement which, with the rise of social media, became a key factor to win these elections. The leader of a band Black Eyed Peas, will.i.am., has produced a video called "Yes We Can", in which the parts of the Obama speech have been shown, while the celebrities were endorsing his candidature. The involvement of such influential and ethnically diverse public figures as Scarlett Johansson, Kareem Abdul-Jabbar, Common or Amaury Nolasco (the then star of the Prison Break TV series), has let Obama reach out for numerous demographics. The third aspect, that has made the social media influential, was the creation of political blogs and media, which were not only focusing on the development of the campaign on the Internet, but also enabled the citizens to debate online and exchange their political views. However, it has led to the creation of the phenomenon called a "media activist bubble", which means that both using Internet mechanisms and cookies as well as frequent use of the Internet for political reasons, close a voter in a bubble, in which he only receives the information related to his political objectives which decreases the influence of the opposite views. In conclusion, Barack Obama is seen as the main winner of such transformation of Internet politics, mainly because of the creation of his website mybarackobama.com on which his supporters could organize events, recruit friends, offer feedback and fundraising drives, while providing the campaign staff with a whole lot of information about themselves [Panagopoulos 2009: 10]. 


\section{FIRST TRULY INTERACTIVE PRIMARIES? HOW THE YEAR 2016 CHANGED THE CAMPAIGNING GAME}

As eight years have passed by, social media have become the most important part of the political campaign in the United States. The statistics show that the influence of the Internet on everyday life of Americans is growing - according to the Pew Research Center estimate, $62 \%$ of Americans get the news from social media [Gottfried, Shearer 2016]. Since the last presidential elections of 2012, the percentage has increased by $13 \%$. What is more, according to the same research centre, in $2016,79 \%$ of Americans used Facebook, 32\% of them used Instagram and 24\% had a Twitter account. It is interesting to note that even though young adults are the largest group that uses the social media, older Internet users seem to more eagerly engage in social media $-62 \%$ of online adults aged 65 and older use Facebook, which is $14 \%$ more than in 2015. It is visible that social media became an important part of the voter's private life, so why do not fully implement it into his/her political decisions? The campaign for the position of the party's nominee in the general presidential election has shown that nowadays political marketing and Internet 2.0 explore each other's fields of research. The ongoing transformation of the marketing, linked to the development of the social apps, can be observed especially in 2016, when their popularity has reached mainstream Internet users. To explore the nature of this subject, I have analysed the political campaigns of four most important politicians, who were fighting during the primaries: Bernie Sanders and Hillary Clinton in Democratic primaries and Ted Cruz and Donald Trump in the Republican primaries.

\section{FEELING THE BERN}

Bernie Sanders, an experienced senator from Vermont was not as popular as the ex-Secretary of State Hillary Clinton, but was able to battle her until the last state primaries. This situation has been created by a buzz generated in the social media, which were used in the most clever way by his political campaign staff. Sanders' Twitter account has gained two million followers, which may be three times less than Clinton's, but the political experts advised that his form of communication with the voters within this medium has been more personalized. The main hashtag that has been linked to his campaign was \#Feelthebern, which became a slogan that helped to reach out to the youngest voters. One of the most important turning points of Sanders' campaign was the first Democratic debate, that took part in Las Vegas on 13 October 2015. Twenty-seven-year-old social media advisor of Sanders, Hector Sigala, who was taking care of the political campaign on this platform, has made simple moves, which have let Sanders win the debate on the Internet. In order to make his candidate the most popular one on Twitter, he decided to go with "hashtag hijacking" - a process in which in a Twitter post, a trending hashtag is used next to 
a hashtag that needs attention. The supporters of Sanders started posting on Twitter with a hashtag \#DemDebate related to the debate, but they also used a hashtag \#DebateWithBernie to show their support [Fares 2016]. Sigala has also been posting from Sanders' official account during the commercial break - during the commercial with Tom Hanks he posted: "Tom Hanks. Finally. Somebody, who makes some sense. \#GOPDebate \#DebateWithBernie". This tweet became very popular and showed Sanders distancing himself from the other candidates [Fares 2016].

His campaign, however, did not rely only on Twitter. In March, Sanders' campaign staff decided to organize a last-minute rally, while using only the social media tools. This has not been the first time they used new media to organize events. The Iowa Caucus campaign has been supported by a nine-day campaign on Snapchat, which is the most popular application amongst youngsters [Shields 2016]. Such a decision was a spot-on idea mainly because young, liberal voters are more eager to share their political views on the Internet and are more likely to use the social media applications on a daily basis. On Facebook, Sanders gathered almost 4.5 million likes, but the personalized posts were not his greatest weapon. Since he became the phenomenon amongst Internet users, they have started to handle his campaign - an ideal example of such behaviour is a Facebook group called Bernie Sanders' Dank Meme Stash, on which almost 500,000 users exchange memes and virals linked to the candidate. The most popular one - Bernie or Hillary - became an Internet hit that fueled the campaign amongst the Facebook users. The meme displayed an infographic on which Bernie Sanders and Hillary Clinton have shared their opinions on various matters (from political views to taste in music or memes), while obviously showing the ex-Secretary of State in a bad light.

With Twitter, Facebook and Snapchat used as the most powerful social media tools in the 2016 presidential campaign, the senator from Vermont has used less popular media to get to specific social groups. For example, his campaign staff has been relying heavily on Slack, where the volunteers could organize his events with the dominating role of Coders for Sanders, a group which focused on the development projects. Sanders' campaign has been also fueled by Reddit, on which his supporters had been posting his political views and information regarding caucuses. They have created a subreddit post called /r/SandersForPresident, which had over 200,000 subscribers [National Journal 2015]. Die-hard supporters of Sanders have even taken the campaign to Tinder, a dating application on which they had been chatting with people not only to date them, but also to endorse the senator. This tactic, however, was good and bad at the same time, since some of the Bernie supporters got banned from this application for spamming.

The devotion of the supporters helped the senator from Vermont become the face of the revolution inside the Democratic Party, but may be inconvenient for the party in the end. The supporters of Sanders, who believe in change of the way the party is thinking, have not stopped canvassing for him even when he lost the primaries. Currently trending hashtag \#BernieOrBust is a slogan used by his supporters, 
who do not want to endorse Hillary Clinton who won the primaries. Even Sanders must have realized that his phenomenon went too far - when he officially supported Clinton in the general elections, he met with the backlash from his supporters, who would rather turn to the third-party candidates such as libertarian Gary Johnson, or Jill Stein representing the Green Party.

The last issue linked to his campaign is the celebrity endorsement - Sanders was able to collect some of the most influential celebrities known for their left-wing oriented political activity. Famous actors such as Mark Ruffalo, Susan Sarandon, Tim Robbins, Juliette Lewis or Danny Glover have been publicly supporting him during the election rallies and helped him gain the trust of the left-wing voters. Sanders has also gained the trust of the famous people, who influence the young voters, such as rappers Killer Mike, T.I. or Lil B - especially the first of them, who became his closest celebrity aide, by providing speeches during the public events. Nonetheless, this did not help Sanders to gain the trust of the ethnic minorities, who strongly supported Clinton. This type of celebrity endorsement can be defined as an endorsement that is focusing on the substantive issues, rather than on the cultural or social background of the endorsing one.

\section{HILLARY CLINTON VS. THE SOCIAL MEDIA}

The campaign of Bernie Sanders has been met cult following in social media, but Hillary Clinton has also transformed her media activity into more user-friendly media. Both Sanders and Clinton were able to launch interesting websites that provided information regarding the campaign itself, political beliefs, campaign trials and the donations, which helped the citizens engage in their movements. From the beginning, the campaign of Sanders has been famous for the small donations that have been provided by his supporters in contrary to the huge budget that Clinton has been contributed by the Super PAC, independent political action committees who can raise more money for the endorsed one than an average American citizen (USD 2,700). The outstanding number of small contributions helped Sanders raise over USD 185 million until the end of March. As it was becoming obvious that Sanders would lose the primaries, Clinton's supporters started to slowly overtake Sanders, having raised USD 238 million until the end of June, when compared to USD 229 million raised by Sanders. It can be seen, however, that Clinton has been supported by wealthier Americans. The statistics show that around $68 \%$ of the contributions were provided by the Large Individual Contributions, while Sanders aimed at the Small Individual Contributions and this is what made his campaign moving (in March he raised around 2 million contributions from individual citizens) [OpenSecrets Report 2016].

Hillary Clinton's main advantage in the campaign for the nomination was her popularity. As the ex-Secretary of State, she was strongly relying on her Twitter followers - she is currently followed on this social media platform by 8.1 million 
people, whereas Sanders has 5 million fewer supporters. Her main hashtag is a slogan \#Imwithher which is an attractive move to show not only the support for Clinton herself, but also for women in politics. On the contrary to the content posted by Sanders, strongly linked to economic issues, which were quite narrow and targeted at identified social groups, Clinton's posts focused on rather mainstream issues, which could attract a wide variety of voters. That is why the supporters of Sanders are mostly representing the white, middle-class, he was not able to attract the minorities, because they care about other issues. A term which has been defined and linked to this situation is called "White Narcissism" and refers to the situation in which the left-oriented white liberals focus on revolutionary issues, which would mostly benefit them. Clinton, however, with her calm message, represents the stability that has been the leitmotif of Obama's presidency - the overview of her campaign is seen as the continuation of his political agenda. Her Twitter campaign has been acclaimed by the analysts because of the form of her posts - each of her tweets contained a shortened URL link, which encouraged the reader to go out to the trackable source page, on which the supporter could register and be identified as a potential donor and volunteer [Scharff 2015]. This way of posting has been, according to Reed Scharff, pioneered in a campaign of Obama in 2008 [Scharff 2015].

As the main political rival of Sanders and Trump, Clinton has been struggling on Twitter with the negative hashtags linked to her campaign such as \#whichHillary, a hashtag posted by the supporters of Bernie Sanders and the Black Lives Matter movement, focusing on the police brutality regarding the ethnic minorities, which has flooded her profile with memes showing her change of opinion on the issues such as gun control, universal healthcare or gay marriages [Hanley 2016]. Another negative hashtag that was trending during the primaries was \#Hillarysoqualified, popularized by Bernie Sanders' supporters, which aimed at her being dependent on Super PACs and the Wall Street lobbyists [Hoadley 2016]. On the other hand, Clinton took aim at Donald Trump criticising Barack Obama (who supported her), and her short message - "Delete your account" - sent on 9 June, became a viral sensation. It has been the most popular tweet so far during the campaign with over 480,000 retweets [Ruiz 2016].

Despite the fact that Clinton had less supporters on Facebook than Sanders, her campaign on this platform can be seen as successful. Her presidential launch video has drew 2.1 million views and she was able to gain over 600,000 likes over the first 24 hours [Chariton 2015]. The analysis of her posts has shown that she mainly linked to the content from her website, which was a clever move - supporters on Facebook generated buzz, but with the access to her website they were still able to support her financially. The campaign of Clinton on Facebook gained momentum after she secured the Democratic Party's nomination - on 21 July 2016 she launched "Trump yourself" - an application on Facebook, on which each user representing his social group was able to see what Trump would say about himself. The application represents some of the Trump's most offensive quotes and its aim was to show that 
he did not respect the voters [Brown 2016]. Clinton also launched Snapchat in August 2015. The most important move of Clinton, regarding this application, was also an attack aimed at Donald Trump - at the end of April, using the Snapchat Face Swap filter, she has put Trump's face on the pictures of former presidents with the quotes of Trump offending people to show how bad choice he would be [Heath 2016].

Social media experts believe that Clinton's social media campaign is similar to a new media startup, in which her staff produces content such as blog articles, interactive quizzes and GIFs, which are aimed at the voters engaging in the development of her website [Przybyla 2016]. Nowadays, Internet users need to adopt the information faster, mainly because they are less patient and are exposed to various factors, which may change their preoccupation within a minute.

Clinton also gained huge support from the celebrities. The hashtag \#Imwithher has attracted various female celebrities. She was supported by, among others, Katy Perry, Meryl Streep, Chloë Moretz or Lena Dunham. Her celebrity endorsement is based mainly on cultural and social aspects - famous and successful women are able to influence the female voters and show them that they can make a change for which feminist activists have been struggling for ages. Clinton has been also a favourite of ethnic and sexual minorities - she gained the support of former NBA star Kareem Abdul-Jabbar, Beyoncé or an actress Eva Longoria, who are famous for their fight for the minorities rights and represent the social groups who are often struggling with inequality. What is more, Clinton had the support of the President Barack Obama, who is a role model for many Afro-Americans. The LGBTQIA+ minority in the endorsement of Clinton was also heavily represented, mainly by the TV star, drag queen RuPaul. The public support for Hillary Clinton has also its pop-cultural aspect-recently the official account of the remake movie Ghostbusters has supported her by tweeting the hashtag \#Imwithher. The remake differs from the original by contributing main female characters to the movie [Robinson 2016].

\section{GENERATING THE BUZZ - CELEBRITY POLITICS OF DONALD TRUMP}

Donald Trump, the Republican Party's nominee for the 2016 presidential campaign has based his success on a social media activity. As a famous person and a billionaire, he already had many followers on these platforms, but only when he decided to run for the nomination, his social media activity has exploded. As it has been analysed earlier, the use of social media amongst the voters determines the increased polarization of the politics. The voters are more willing to represent the political views that are supported on the Internet by other web users. This, combined with a narrow simplicity of the forms of the communication of Trump, has clinched his nomination. The campaigning style of Trump is similar to that of Sanders, because he is seen as an anti-establishment persona, what is more - he is not even a politician like Sanders, he is a well-known businessman. Both Trump 
and Sanders are charismatic, but they attract different social groups - while Sanders is supported by a left-wing middle class, Trump is endorsed by conservative, poor people. What is similar is the cult following that they have created - this makes their supporters more loyal, because they perceive them as the leaders. Trump used his celebrity status not only to gain the followers, but also to generate financial profits for his campaign. When displaying Trump's fanpage on Facebook, a button "Shop now" can be seen, which links to a shop on his website, which has a wide variety of gadgets on which his slogan "Make America Great Again" is incorporated. In his Facebook posts, Trump is more likely to link to news posts rather than to his website, which is completely different tactics than the one used by his opponents. He focuses on his media appearances and never posts content from his website, mainly using Fox News and "Daily Mail" as a source [Pew Research Center 2016]. With his narrow message, Trump in an ideal way finds himself in the Internet 2.0 reality, where everyone can anonymously leave any comment they want. He is the voice of these people and with his public profile he can do it because, first of all, he does not rely on the party and, secondly, he attracts the attention of the media, which fuels him.

Trump's most influential way of communicating with the voters is Twitter. Here he shares his personal beliefs, attacks his opponents and, what is interesting, he often retweets posts from his supporters accounts. Currently, Trump has over ten million followers on this platform and it is still growing. As it has been analysed earlier, the businessman does not use social media for the campaign, he is the personification of them. His personal attacks have changed and the political discourse was simplified by creating simple, short and strong messages to his followers. By using a metaphor, the Internet can be described as an overcrowded place in which, in order to be heard, one needs to be the loudest and the most provocative and that is how the Republican candidate operated. In order to win the primaries, he notoriously attacked the opponents from his party to decrease the public trust in them. What people saw in these tweets was the political honesty; by speaking his mind he addresses the biggest frustrations of American citizens disappointed by Obama's eight-year presidency. Political marketing experts believe that this is the way social media start to edge out more collective forms of action such as party apparatuses [Gabler 2016]. This situation has also been created by the weakness of Republican Party favourites who were not either that charismatic or natural in the use of social media to combat their opponent. In the Internet 2.0 era, the mainstream media no longer have control over what is acceptable for the candidate to say in public [Naughton 2016]. This leads to the conclusion that modern political campaigns need to entertain the voter, to keep him informed on the issues. Trump and his voters focus on a common narrative, that is far from the fact-checking and with the polarization of the opinion on the Internet, a media bubble is created in which these voters can exchange their political beliefs without listening to the other side. Justin McConney, who was a marketing strategist of Trump, had been encouraging him to give his fans the controversy, because that 
would be something that would entertain them [Roussi 2016]. He operated on emotions rather than on substantive issues, which is why he was able to gain such support.

Another social media platform on which Trump operates is Instagram. Instagram has of course been used by the Democratic candidates such as Clinton or Sanders as well (it even has been used as the way of endorsement by Zoë Kravitz who supports Sanders), but Trump uploads numerous short videos in which he mocks his rivals, releases short statements and shows how he spends time with his family. However, his followers on various social media platforms are generally not American citizens. The study shows that only $42 \%$ of his Facebook followers are located in the United States with many of them coming from the developing countries meaning that a huge part of these likes may be from the fake accounts and social media frauds [Parkinson 2015]. His numbers are impressive, but one may call into question whether his online popularity follows the popularity in real life. It is also worth noting that Trump was the first candidate to set the Periscope platform to stream weekly Q \& A sessions.

\section{THE RISE AND FALL OF THE REPUBLICAN STAR - ANALYSING THE CASE OF TED CRUZ}

The last candidate that has gained an impressive social media following was a United States Senator from Texas, Ted Cruz. He first caught the attention of media at the beginning of 2011, when he announced his Senate run on a conference call with the conservative bloggers. With two full-time staffers concentrated on the Facebook activity he became a star of the right-wing new media and he shortly became the pundit's favourite for the Republican Party nomination in 2016. With small financial resources, Cruz decided to rely on social media instruments, which gained him the online media support - that is why he launched a website cruzcrew. org, on which he encouraged his volunteers to print his campaign literature and canvass for him. He even has been named "The Barack Obama of 2012" by the experts from "Politico" [Friess 2012]. As the Republican Party primaries were coming close, Cruz has already established an important position within a party. Josh Perry, now a 27-year-old social media advisor of the Senator, wanted to follow the successful campaign of 2012 while using the same tools that helped Cruz reach the voters. Cruz launched his presidential campaign in March 2015, when he uploaded a 30-second video on the Twitter platform, followed by a Facebook video post that reached 1 million Facebook users [Chittal 2015]. At that time, Cruz had 1.2 million Facebook followers, 400,000 more than even Hillary Clinton or Marco Rubio, who was supposed to be his biggest rival. At the beginning of the campaign, Cruz still was social media's favourite - according to the analytics platform Zoomph, he had the highest score related to the activity of the candidates regarding the social media during the GOP debate in October 2015 - he received almost 27,500 engagements on Twitter, Google+, Twitter and Instagram [Moon 2015]. This success has been fol- 
lowed by launching of the Cruz Crew application, on which every day his supporters could check their activity in canvassing for the candidate in order to make their way to the top of the leaderboard. To gain the points, his supporters had to post pro-Cruz messages on Facebook, donate money or sign up to volunteer [Detrow 2015]. His political staff, however, had been using social media too aggressively - it has been uncovered, at the end of 2015 that Cruz had been cooperating with a startup that had paid the researchers at the Cambridge University to gather psychological data about the US Facebook users. This has been used to match the user's likes on Facebook with the voter datasets, such as the gun-owning [Davies 2015]. All these actions have helped Cruz win the Iowa Caucus and he was able to get over $27 \%$ of the votes. Personal-based data modelling and the activity of his supporters via his mobile apps have guaranteed him the publicity needed for the win. The activation of his voters via microtargeting and direct communication through Internet 2.0 resources and doorto-door campaigning were the key to his success [Patterson 2016]. This, however, was the beginning of his fall. It can be easily said that Ted Cruz became the victim of social media, which have destroyed his campaign. His outstanding use of these tools was impressive, but could not compete with the activity of other users, who were doing their best to let all the mistakes of Cruz go viral. A tweet posted in 2013 after Cruz's speech at the Conservative Political Action Conference, stating that his speech is called "This is the Zodiac Speaking", referring to a famous serial killer, seemed like an innocent joke, but during the campaign, became one of the most recurring jokes. This meme worked the same way as Republicans were attacking Obama in 2008 - when they started to insist that his birth certificate was fake and that he was born in Kenya, people started to believe it [Dean 2016]. With Texas Senator's rather shy personality, opposed to a vigorous and strong image of Trump, he was the easiest target for Internet users. People did not care that Cruz was born in 1970 and Zodiac committed his first murder in 1968, the joke had become the part of the political discourse and with every tweet or meme posted on the Internet, the chances of Cruz being taken seriously were drastically lowering. This viral has quickly been caught by the standard media and respected journalists, who started to debate this issue. This was only the beginning, because Cruz's appearance in the media was generating new virals - especially amongst the users of Vine, a social media tool on which users may post short videos. A video of Cruz eating a booger during the Republican debate or unsuccessfully exchanging handshake with his running mate became a viral hit - the second video was seen over 7 million times [Alexander 2016]. These awkward moments could be forgiven in the old world of traditional media, but not in the world of the Internet 2.0, where everyone does their best to post the most popular and controversial content. The meme campaign against Cruz, fueled mostly by the Bernie Sanders Meme Stash group started to depreciate Cruz, especially in the eyes of young voters and the grotesque mistakes made by Cruz were only providing more amusement, which helped Trump's campaign. While the anti-Trump or anti-Clinton Internet campaign was rather focusing on the substantive 
issues, the anti-Cruz campaign was mainly to entertain Internet users. The jokes reached their peak moment around March and April, just when the caucus results all over the United States started to ensure Trump's victory. Once a person becomes viral on the Internet, it is really hard to divert the attention of social media, because the users will try to post more and more content. The decreasing popularity of Cruz amongst the Republican voters has made Cruz end his campaign, but it did not end the campaign of memes against him. A video of Cruz accidentally punching his wife in the face with an elbow during his campaign-ending conference [Alexander 2016], or a story on Cruz's female doppelgänger, who was offered USD 10,000 to do an amateur porn [Moye 2016] were still catching the attention of the media and with Cruz not addressing these virals he still was the easiest target for web users.

\section{CONCLUSIONS}

When analysing the United States presidential primary campaign, it can be easily spotted that the use of social media both amongst the voters and the candidates is increasing and is becoming the most important issue, with the traditional media getting less attention. This situation has been created mostly thanks to the public access to the Internet amongst US citizens and their willingness to create the content. Of course, traditional ways of canvassing, such as door-to-door campaigning and TV spots and appearances still play an important role in the political marketing process, but the voters need to interact with their candidates and are encouraging them to seek more personal contact with them. Because of the social media tools, the distance between the voter and the candidate is no longer visible and these two political actors can create bonds, which generate profits to both of them. The voter is able to see a more personal-oriented side of the candidate and is able to influence his campaign, while the candidate can acknowledge their support by creating personal messages. With the use of social media, political staff can create the campaign that lets reach out to more political supporters, while spending less money. Thanks to this, a politician can be seen as someone, who represents the voter's values, while being an average citizen, just like the voter. The world of social media apps is still developing and with every another elections, new applications can be created, that will help the politicians canvass in more spectacular way. Internet 2.0's main advantage is that the Internet user no longer receives the information, he can also provide it and create the content, which, when moved to the world of the political marketing, can be a tool that lets the voter co-create the campaign. More Internet users engaged in the campaign mean more human and financial resources, which are the key aspect of every successful campaign. The viral aspect of marketing can bring both positive and negative results, which show the power of the Internet, because once a content appears on the Internet, it stays there forever. Nowadays, the candidates need to be more cautious because their every step is followed by millions of users. The casus 
of Ted Cruz's campaign shows that even with the best social media-oriented staff, the campaign can be buried by memes and virals that show the candidate in a bad light. The Internet is the main power in the hands of young voters, that is why the campaign of Bernie Sanders has been heavily fueled by the Internet users and that is why he received the least negative feedback. His supporters were creating the most of the negative content towards other candidates. The celebrity endorsement plays an important part in this process, with millions of followers, the celebrities have the power not only to interact with their fans, but also to craft their political views and influence their decisions.

Finally, taking into consideration the results of the presidential elections in the United States, it can be acknowledged that with the influence of social media, a modern voter has been created, who focuses on the entertainment, as the leading factor determining his political decisions. While the political program of the candidate is important for him, he more eagerly focuses on how the issues are presented to him. The whole campaigning process is transformed into a reality show, in which the more buzz and hype is generated by the candidate, the more chances of winning he has. Is this a way to somehow encourage the non-voting citizens to take part in the elections? It is definitely worth trying, but the politicians and media need to take responsibility for the content they are sharing in the media to ensure that the voter is not misinformed.

\section{BIBLIOGRAPHY}

Alexander, L. 2016. Blame it on the Zodiac killer: did social media ruin Ted Cruz's campaign?, https:// www.theguardian.com/media/2016/may/04/ted-cruz-campaign-social-media-memes-zodiac-killer (access: 09.08.2016).

Austin, E., Van de Vord, R., Pinkleton, B., Epstein, E. 2008. Celebrity Endorsements and Their Potential to Motivate Young Voters, "Mass Communication and Society", vol. 11 (4).

Bourdieu, P. 1984. Distinction: A Social Critique of the Judgement of Taste, Harvard University Press, Harvard.

Brown, N. 2016. Hillary Clinton campaign launches 'Trump yourself' filters for Facebook, http:// www.amny.com/news/elections/hillary-clinton-campaign-launches-trump-yourself-filters-for-facebook-1.12075440 (access: 10.08.2016).

Chariton, J. 2015. Hillary Clinton Takes Facebook by Storm After Joining, http://www.thewrap.com/hillaryclinton-takes-facebook-by-storm-after-joining (access: 19.06.2016).

Chittal, N. 2015. How Ted Cruz's digital team wants to win the Internet in 2016, http://www.msnbc.com/ msnbc/how-ted-cruz-digital-team-wants-win-the-internet-2016 (access: 07.07.2016).

Davies, H. 2015. Ted Cruz using firm that harvested data on millions of unwilling Facebook users, https:// www.theguardian.com/us-news/2015/dec/11/senator-ted-cruz-president-campaign-facebook-user-data (access: 31.07.2016).

Dean, M. 2016. Ted Cruz is the Zodiac killer: the anatomy of a meme gone rogue, https://www.theguardian. com/us-news/2016/mar/09/ted-cruz-zodiac-killer-meme (access: 14.07.2016).

Detrow, S. 2015. Cruz's Crew: You Play the Game, but It's the Cruz Campaign That Scores, http://www. npr.org/2015/11/09/455225893/cruzs-crew-you-play-the-game-but-its-the-cruz-campaign-that-scores (access: 01.08.2016). 
Fares, M. 2016. How a 27-year-old ghost tweeter keeps Bernie Sanders'message resonating, http://www. businessinsider.com/bernie-sanders-twitter-strategy-2016-4?IR=T (access: 02.08.2016).

Friess, S. 2012. Cruz's secret: Mastering social media, http://www.politico.com/story/2012/07/contenders-secret-mastering-social-media-079213 (access: 14.06.2016).

Fuchs, Ch., Boersma, K., Albrechtslund, A., Sandoval, M. (eds.), 2012. Internet and Surveillance: The Challenges of Web 2.0 and Social Media, Routledge, New York.

Gabler, N. 2016. How the Media Overthrew Party Politics, http://billmoyers.com/story/media-overthrew-party-politics (access: 23.07.2016).

Gottfried, J., Shearer, E. 2016. News Use Across Social Media Platforms 2016, http://www.journalism. org/2016/05/26/news-use-across-social-media-platforms-2016 (access: 16.06.2016).

Gueorguieva, V. 2009. Voters, MySpace and YouTube. The Impact of Alternative Communication Channels, [in:] Politicking online: The Transformation of Election Campaign Communications, C. Panagopoulos (ed.), Rutgers University Press, New Brunswick.

Gulati, G., Williams, C. 2007. Social Networks in Political Campaigns: Facebook and the 2006 Midterm Elections, Bentley College Department of International Studies, Waltham.

Gulati, G., Williams, C. 2014. Relationship Marketing in Social Media Practice: Perspectives, Limitations and Potential, [in:] Political Marketing in the United States, J. Lees-Marshment, B. Conley, K. Cosgrove (eds.), Routledge, Oxon.

Hanley, B. 2016. Anti-Hillary Clinton Hashtag Breaks the Internet 2 Days Before South Carolina Prima$r y$, http://www.huffingtonpost.com/brian-hanley/anti-hillary-clinton-hash_b_9322034.html (access: 14.07.2016).

Harvey, K. 2013. Encyclopedia of Social Media and Politics, Sage Publications, Thousand Oaks.

Heath, A. 2016. Hillary Clinton just invented the Snapchat attack ad, http://www.techinsider.io/hilaryclintons-snapchat-trolls-donald-trump-2016-4 (access: 17.07.2016).

Henneberg, S., Chen, Y-L. 2008. Celebrity Political Endorsement: Campaign Management for the Taipei City Councillor Election 2002, "Journal of Political Marketing", vol. 6 (4).

Hoadley, G. 2016. Hillary Clinton hashtag \#hillarysoqualified goes viral, which is bad news for her, http:// www.inquisitr.com/2970889/hillary-clinton-hashtag-hillarysoqualified-goes-viral-which-is-bad-newsfor-her (access: 17.07.2016).

Howard, P., Chadwick, A. 2010. The Routledge Handbook of Internet Politics, Taylor \& Francis, Oxon.

Jackson, D. 2008. Selling Politics: The Impact of Celebrities' Political Beliefs on Young Americans, “Journal of Political Marketing", vol. 6 (4).

Kotler, P., Armstrong, G. 1990. Marketing: An Introduction, Prentice-Hall, Upper Saddle River.

Lees-Marshment, J. 2004. The Political Marketing Revolution: Transforming the Government of the UK, Manchester University Press, Manchester.

Marland, A., Lalancette, M. 2014. Access Hollywood: Celebrity Endorsements in American Politics, [in:] Political Marketing in the United States, J. Lees-Marshment, B. Conley, K. Cosgrove (eds.), Routledge, New York.

Moon, A. 2015. Ted Cruz steals the social media spotlight, http://blogs.reuters.com/talesfromthe trail/2015/10/28/ted-cruz-steals-the-social-media-spotlight (access: 01.08.2016).

Moye, D. 2016. 'Female Ted Cruz' Porno Hits Web Same Day Cruz Ditches Campaign (NSFW), http:// www.huffingtonpost.com/entry/female-ted-cruz-porn-released-same-day-candidate-quits-campaign us_572b6b97e4b016f37894decc (access: 11.08.2016).

National Journal. 2015. Bernie Sanders Is Dominating the Reddit Primary, https://www.nationaljournal. $\mathrm{com} / \mathrm{s} / 74398 /$ bernie-sanders-is-dominating-reddit-primary (access: 02.08.2016).

Naughton, J. 2016. Why social media is the real Trump card in the US election, https://www.theguardian. com/commentisfree/2016/apr/03/donald-trump-internet-success-twitter-us-election-media (access: 25.07.2016).

OpenSecrets Report, 2016. Candidate Summary, 2016 Cycle, https://www.opensecrets.org/pres16/candidate. php?id=N00000019 (access: 20.07.2016). 
O'Reilly, T. 2005. What Is Web 2.0: Design Patterns and Business Models for the Next Generation of Software, http://www.oreilly.com/pub/a/web2/archive/what-is-web-20.html (access: 01.07.2016).

Panagopoulos, C. 2009. Technology and the Modern Political Campaign: The Digital Pulse of the 2008 Campaigns, [in:] Politicking Online: The Transformation of Election Campaign Communication, C. Panagopoulos (ed.), Rutgers University Press, New Brunswick.

Parkinson, H.J. 2015. Can Donald Trump's social media genius take him all the way to the White House?, https://www.theguardian.com/technology/2015/dec/23/donald-trump-social-media-strategy-internet-republican-nomination-president (access: 08.08.2016).

Patterson, D. 2016. Election Tech: Big data is the new ground game: how Ted Cruz won Iowa, http:// www.techrepublic.com/article/big-data-is-the-new-ground-game-how-ted-cruz-won-iowa (access: 11.07.2016).

Pew Research Center Report. 2016. 2. Candidates differ in their use of social media to connect with the public, http://www.journalism.org/2016/07/18/candidates-differ-in-their-use-of-social-media-to-connect-with-the-public (access: 19.07.2016).

Przybyla, H.M. 2016. Clinton media campaign follows BuzzFeed model, http://www.usatoday.com/story/ news/politics/elections/2016/01/18/hillary-clinton-social-media-trump-twitter-facebook/78856358 (access: 10.07.2016).

Robinson, W. 2016. Ghostbusters Twitter account endorses Hillary Clinton: '\#ImWithHer', http://www. ew.com/article/2016/07/27/ghosbusters-endorse-hillary-clinton (access: 09.08.2016).

Roussi, A. 2016. The Twitter candidate: Donald Trump's mastery of social media is his real ground game, http://www.salon.com/2016/02/18/the_twitter_candidate_donald_trumps_mastery_of_social_media_is_his_real_ground_game (access: 18.07.2016).

Ruiz, R. 2016. How the Clinton campaign is slaying social media, http://mashable.com/2016/07/25/inside-social-media-hillary-clinton/\#fCDmi.vKRGqy (access: 19.07.2016).

Scharff, R. 2015. The candidate winning on social media, http://www.cnbc.com/2015/10/14/the-candidate-winning-on-social-media-hillary-clinton-commentary.html (access: 12.07.2016).

Shields, M. 2016. Bernie Sanders Is Running a 9-day Snapchat Ad Campaign in Iowa, http://www.wsj. com/articles/bernie-sanders-is-running-a-9-day-snapchat-ad-campaign-in-iowa-1453806001 (access: 08.08.2016).

Wiszniowski, R. 2000. Marketing wyborczy. Studium kampanii wyborczych w systemach prezydenckich i semiprezydenckich (Finlandia, Francja, Polska, Stany Zjednoczone), PWN, Warszawa.

\section{BIOGRAPHY}

Norbert Tomaszewski, a PhD student at the University of Wrocław, Institute of Political Science. In his scientific work, he focuses on the influence of social media and celebrity endorsement on the voting behaviour in the United States. He also studies cultural, pop-cultural and social aspects of the political campaign in the United States. E-mail: nntomaszewski@gmail.com 